\title{
MOLECULAR CHARACTERIZATION OF INFLUENZA B VIRUS OUTBREAK ON A CRUISE SHIP IN BRAZIL 2012
}

Samanta Etel Treiger BORBOREMA, Daniela Bernardes Borges da SILVA, Kátia Corrêa Oliveira SILVA, Margarete Aparecida Benega PINHO, Suely Pires CURTI, Terezinha Maria de PAIVA \& Cecília Luiza Simões SANTOS

\begin{abstract}
SUMMARY
In February 2012, an outbreak of respiratory illness occurred on the cruise ship MSC Armonia in Brazil. A 31-year-old female crew member was hospitalized with respiratory failure and subsequently died. To study the etiology of the respiratory illness, tissue taken at necropsy from the deceased woman and respiratory specimens from thirteen passengers and crew members with respiratory symptoms were analyzed. Influenza real-time RT-PCR assays were performed, and the full-length hemagglutinin (HA) gene of influenzapositive samples was sequenced. Influenza B virus was detected in samples from seven of the individuals, suggesting that it was the cause of this respiratory illness outbreak. The sequence analysis of the HA gene indicated that the virus was closely related to the B/ Brisbane/60/2008-like virus, Victoria lineage, a virus contained in the 2011-12 influenza vaccine for the Southern Hemisphere. Since the recommended composition of the influenza vaccine for use during the 2013 season changed, an intensive surveillance of viruses circulating worldwide is crucial. Molecular analysis is an important tool to characterize the pathogen responsible for an outbreak such as this. In addition, laboratory disease surveillance contributes to the control measures for vaccine-preventable influenza.
\end{abstract}

KEYWORDS: Influenza B; Sequencing; rRT-PCR; Outbreak; Acute respiratory infection; Cruise ship.

\section{INTRODUCTION}

Cruise ship holidays are increasing in popularity worldwide. In Brazil, since the 2004-05 season, there has been a considerable increase in both the number of ships and in the number of routes. In the 2010-11 season along the Brazilian coast, there were approximately 800,000 cruise passengers, including 100,000 foreigners, traveling on twenty cruise ships ${ }^{1}$. The nature of the cruise ship environment - enclosed and semi-enclosed compartments - may facilitate rapid transmission of infectious agents among passengers and crew members. Influenza viruses can easily spread when introduced into confined, crowded environments, and outbreaks of disease may accompany the expected increase in these leisure activities ${ }^{9}$. Summer season influenza outbreaks among passengers and crew members on cruise ships suggest that traveling in large groups can pose a risk for exposure to influenza viruses, even when the travel is in regions where influenza is not in seasonal circulation ${ }^{4}$.

Influenza outbreaks have been previously reported on cruise ships in Australia ${ }^{3,21}$, Canada and the USA ${ }^{10,20}$. To our knowledge, our investigation is the first characterization of an influenza virus outbreak onboard a cruise ship on the Brazilian coast.

On 17 February 2012, the Epidemiological Surveillance Centers of the city of Santos and the state of São Paulo (CVE) reported to the Brazilian Ministry of Health the death of a 31-year-old female crew member from the cruise ship MSC Armonia (MSC Cruzeiros Ltda) during a summer season in Brazil. The crew member presented with acute respiratory infection, and on 15 February 2012 was admitted to the intensive therapy unit with respiratory failure and died $^{11}$. After interviewing the cruise ship's physicians and health care providers of the cities of Santos and Guarujá, thirteen more cases of passengers and crew members with symptoms of an influenza-like syndrome were identified ${ }^{11}$. Facing a clinical diagnosis of influenza-like illness (ILI), respiratory samples were collected and sent to the Institute Adolfo Lutz for investigation. Our study was conducted to identify the etiology of the respiratory illness outbreak and to perform the molecular characterization of the pathogen.

\section{STUDY DESIGN}

1. Clinical specimens: Fourteen respiratory specimens (throat and/or nasopharyngeal swabs, nasopharyngeal aspirate and tracheal secretion) were collected from the thirteen passengers and crew members identified by the cruise ship's physicians and health care providers of the cities of Santos and Guarujá and sent to the Adolfo Lutz Institute. Individuals with respiratory symptoms such as a fever, cough and sore throat of less 


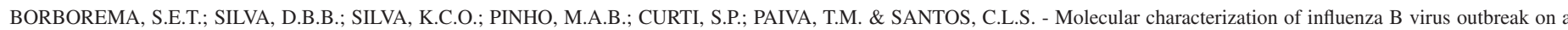
cruise ship in Brazil 2012. Rev. Inst. Med. Trop. Sao Paulo, 56(3): 185-9, 2014.

than seven days duration were eligible for inclusion in this study. Tissue necropsy (lung) from the fatal case was also analyzed. The specimens were obtained from individuals of all ages and genders. Samples were received on wet ice and held at $4{ }^{\circ} \mathrm{C}$ prior to processing within twentyfour hours of receipt.

2. RNA extraction: Total viral RNA was automatically extracted from $200 \mu \mathrm{L}$ aliquot of respiratory sample and eluted in $70 \mu \mathrm{L}$ using a VX viral DNA/RNA extraction kit (QIAxtractor ${ }^{\circledR}$ virus reagent and a QIAxtractor instrument [Qiagen, CA, USA]). RNA from tissue necropsy was manually extracted from $3 \mathrm{~mm}^{3}$ of tissue and eluted in $50 \mu \mathrm{L}$ using a QIAamp RNA blood mini kit (Qiagen, CA, USA). All procedures were performed according to the manufacturer's instructions prior to PCR analysis.

3. Real time RT-PCR Influenza Panel: Samples were analyzed using a standard testing algorithm that included the use of a real-time RT-PCR (rRT-PCR) assay to verify influenza viruses ${ }^{23}$. The Influenza Panel includes oligonucleotide primer and probe sets to detect influenza A(H1N1)pdm09, A(H1N1), A(H3N2) and influenza B viruses. Sequence information for $\mathrm{rRT}-\mathrm{PCR}$ primers and probes was provided by the Centers for Disease Control and Prevention, Influenza Division (CDC, USA). The assays were optimized using an Invitrogen SuperScript ${ }^{\circledR}$ III Platinum One-Step quantitative RT-PCR kit (Life Technologies Corporation, SP, Brazil) and a Roche Light Cycler® 480 real-time PCR system (Roche Diagnostics, SP, Brazil).

4. Sequencing analysis: The full-length hemagglutinin (HA) gene was amplified by RT-PCR and sequenced based on the protocol from the World Health Organization (WHO) ${ }^{22}$. Sequence information for primers was provided by the Influenza Division at the CDC. RT-PCR products were directly sequenced using the ABI PRISM ${ }^{\circledR}$ BigDye ${ }^{\mathrm{TM}}$ Terminators Cycle Sequencing Ready Reaction (Applied Biosystems, CA, USA) with an ABI 3130 Genetic Analyzer (Applied Biosystems, CA, USA). All nucleotide sequences obtained were edited and aligned using Sequencher 4.7 (Gene Codes Corporation, MI, USA) and Bioedit $7.0^{8}$, respectively. Phylogenetic and molecular evolutionary analyses were conducted using MEGA version $5^{19}$. A phylogenetic tree was constructed with the neighbor-joining method, bootstrapped with 1000 replicates. Sequences were compared with a corresponding panel of representative global sequences and vaccine strain for phylogenetic association and polymorphism identification. Representative strains were added to GenBank under accession numbers: JN872376-872404, HM628690-91, JX679215, KC291188-89.

\section{RESULTS}

Influenza B virus strains were identified in seven passengers and crew members (54\%) from a total of thirteen investigated (Table 1). For the crew member who presented respiratory failure and died, both respiratory specimens and lung tissue were analyzed and influenza B virus was detected. All the other individuals were hospitalized; although none experienced respiratory failure, all required observation and were submitted to oseltamivir antiviral treatment.

Based on the available information about the patients' vaccination status, there was no statistically significant difference between the positive or negative result for influenza $B$ viruses of vaccinated and non-vaccinated patients (Table 1).

The complete HA gene of nine influenza B virus strains from the seven positive individuals was sequenced and compared phylogenetically.

Table 1

Analysis of passengers and crew members who presented respiratory symptoms by rRT-PCR Influenza Panel

\begin{tabular}{|c|c|c|c|c|c|c|c|c|c|}
\hline Patients & Samples & Gender & Ages & Collection date & Symptoms date & Samples & $\mathrm{C}_{\mathrm{T}}$ values $^{\mathrm{a}}$ & Results & Influenza Vaccine \\
\hline & 10944 & & & $16 / 02 / 12$ & $12 / 02 / 12$ & Tissue & 23 & Influenza B & \\
\hline \multirow[t]{2}{*}{1} & $9-1089$ & F & 30 & $16 / 02 / 12$ & $12 / 02 / 12$ & $\mathrm{TS}$ & 18 & Influenza B & No \\
\hline & $9-1090$ & & & $16 / 02 / 12$ & $12 / 02 / 12$ & $\mathrm{RS}$ & 22 & Influenza B & \\
\hline 2 & 10968 & $\mathrm{~F}$ & 30 & $17 / 02 / 12$ & $15 / 02 / 12$ & $\mathrm{RS}$ & 33 & Influenza B & Yes \\
\hline 3 & 10969 & M & 27 & $17 / 02 / 12$ & $14 / 02 / 12$ & $\mathrm{RS}$ & 31 & Influenza B & UN \\
\hline 4 & 10970 & M & 23 & $17 / 02 / 12$ & $15 / 02 / 12$ & $\mathrm{RS}$ & 26 & Influenza B & No \\
\hline 5 & 10972 & $\mathrm{~F}$ & 24 & $17 / 02 / 12$ & $15 / 02 / 12$ & $\mathrm{RS}$ & 22 & Influenza B & Yes \\
\hline 6 & 10976 & M & 23 & $18 / 02 / 12$ & $15 / 02 / 12$ & $\mathrm{RS}$ & 26 & Influenza B & No \\
\hline 7 & 10977 & M & 31 & $18 / 02 / 12$ & $16 / 02 / 12$ & $\mathrm{RS}$ & 28 & Influenza B & UN \\
\hline 8 & 10971 & M & 23 & $17 / 02 / 12$ & $12 / 02 / 12$ & $\mathrm{RS}$ & - & Negative & Yes \\
\hline 9 & 10973 & $\mathrm{~F}$ & 37 & $18 / 02 / 12$ & $13 / 02 / 12$ & $\mathrm{RS}$ & - & Negative & No \\
\hline 10 & 10974 & $\mathrm{~F}$ & 12 & $18 / 02 / 12$ & $17 / 02 / 12$ & $\mathrm{RS}$ & - & Negative & UN \\
\hline 11 & 10975 & M & 10 & $18 / 02 / 12$ & $18 / 02 / 12$ & $\mathrm{RS}$ & - & Negative & Yes \\
\hline 12 & 10978 & $\mathrm{~F}$ & 31 & $18 / 02 / 12$ & $17 / 02 / 12$ & $\mathrm{RS}$ & - & Negative & No \\
\hline 13 & 10979 & M & 24 & $19 / 02 / 12$ & $17 / 02 / 12$ & $\mathrm{RS}$ & - & Negative & No \\
\hline
\end{tabular}

$\mathrm{RS}=$ respiratory secretion (throat and/or nasopharyngeal swabs and nasopharyngeal aspirate); $\mathrm{TS}=$ tracheal secretion; Tissue necropsy $=$ lung. ${ }^{\mathrm{C}} \mathrm{C}_{\mathrm{T}}=$ threshold cycle value for rRT-PCR Influenza B assay. UN = uninformed 
BORBOREMA, S.E.T.; SILVA, D.B.B.; SILVA, K.C.O.; PINHO, M.A.B.; CURTI, S.P.; PAIVA, T.M. \& SANTOS, C.L.S. - Molecular characterization of influenza B virus outbreak on a cruise ship in Brazil 2012. Rev. Inst. Med. Trop. Sao Paulo, 56(3): 185-9, 2014

All strains were genetically characterized as influenza B viruses belonging to the Victoria lineage. Sequence analysis showed the closest similarity $(99.2 \%)$ to the HA of vaccine strain B/Brisbane/60/2008, the influenza B virus lineage circulating in state of Sao Paulo during 2012 influenza season. The strains were also similar to other influenza B strains isolated in our laboratory from patients with ILI and severe acute respiratory infection (SARI) at about the same period.

Results shown in Fig. 1 revealed that all strains from the cruise ship's outbreak formed only one branch in the phylogenetic tree and clustered very closely to $\mathrm{B} / \mathrm{Brisbane} / 60 / 2008$. Considering the strains isolated during January 2010 to February 2012, both the B/Victoria/2/87 and the $\mathrm{B} /$ Yamagata/16/88 lineages circulated. However, the Victoria lineage was

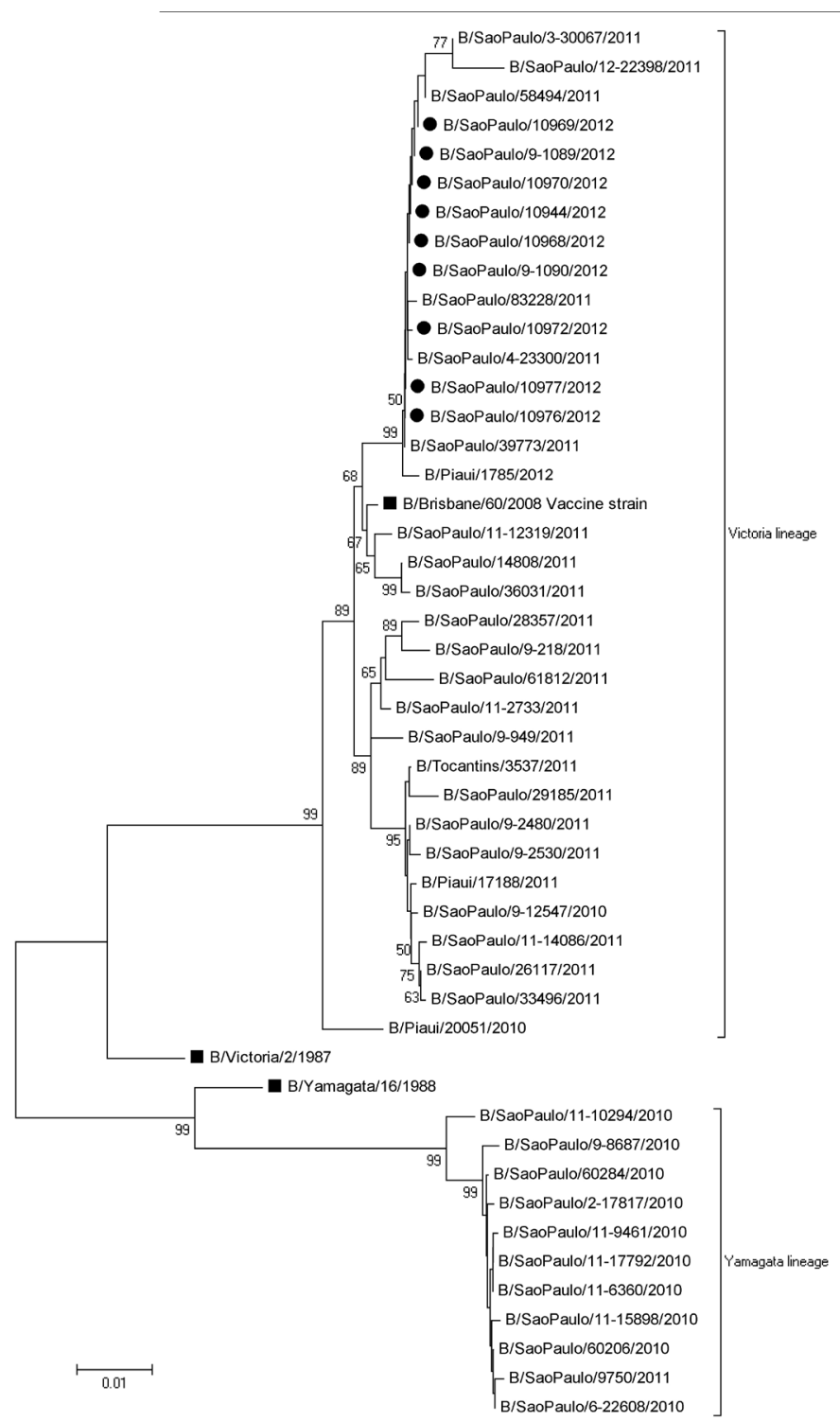

Fig. 1 - Phylogenetic tree of a full-length HA gene of influenza B sequences. Tree was constructed by neighbor-joining method (Kimura 2-parameter) using MEGA version 5 . Numbers at the nodes indicate the bootstrap confidence levels. Reference strains are labeled with a square $(\boldsymbol{\square})$; $(\mathbf{O})$ black circle = sequences of passengers and crew members. more prevalent than the Yamagata lineage, with 34 versus 11 strains, respectively. The B-Victoria lineage predominated during the 2011-12 influenza seasons (32/33). The majority of influenza B virus strains identified by our surveillance system shared an amino acid substitution at positions I146V (30/45) and L58P (11/43) in the HA compared with the vaccine virus.

\section{DISCUSSION}

On 20 February 2012, the Adolfo Lutz Institute reported that the influenza B virus was detected in seven individuals, implicating the influenza B virus as the cause of a respiratory illness outbreak onboard the cruise ship. Sequence analysis of the HA gene of influenza B strains indicated that the viruses were closely related to a B/Brisbane/60/2008like virus belonging to the Victoria lineage, the vaccine virus for the 2011-12 southern hemisphere influenza seasons. Although the amino acid changes at I146V and L58P positions, neither substitution has a marked affect on the antigenicity of the viruses ${ }^{7}$. No significant differences were detected among the amino acid residues within the HA receptor binding sites of influenza B viruses.

Although influenza virus outbreaks on cruise ships have not been frequently reported, they represent a great public health concern. In 2000, an outbreak of influenza B was described in Northern Europe, with a total of $64(13 \%)$ crew members and $54(4 \%)$ passengers identified with Acute Respiratory Infection (ARI) ${ }^{4}$. BROTHERTON et al. ${ }^{3}$ also reported an outbreak on a cruise ship sailing between Australia and New Caledonia involving $37 \%$ of the passengers; both influenza A and B viruses were circulating on the ship.

Influenza viruses are easily spread by droplets and aerosol produced by an infected person; semi-enclosed environments can facilitate the transmission and are difficult to control. The cruise ship MSC Armonia travelled for three nights along the Brazilian coast (Santos/Ilha Grande/ Angra dos Reis/Ilhabela/Santos) and carried approximately 2,000 passengers and 800 crew members. They are from different regions, intermingle for extended periods in the same compartments and, after leaving the cruise, travelers disperse and may spread acquired infections. These facts highlight the great potential of travel in the rapid dissemination and global spread of new influenza viruses. Specific management to control the outbreak should include: (1) early identification and isolation of crew members and passengers with ILI; (2) implementation of good respiratory hygiene and cough etiquette (wearing protective masks or respirators, washing hands with soap and water, covering mouth and nose with a tissue and discarding it in the trash after use); (3) use of influenza antiviral medications for the treatment of persons with suspected or confirmed influenza; and (3) use of antiviral chemoprophylaxis on exposed persons ${ }^{12}$.

Moreover, to decrease the exposure risk to influenza viruses, people should be advised that pre-existing major medical conditions (diabetes, chronic lung diseases, immunodeficiency) can increase the likelihood of illness. Travelers with a high risk of complications and all crew members should consider getting an influenza vaccination before travel. The CDC recommends a yearly influenza vaccine as the first and most important step in protecting against influenza viruses. People taking a summer cruise who were vaccinated during the previous season are still protected and do not need to get vaccinated again until the following influenza season. 
BORBOREMA, S.E.T.; SILVA, D.B.B.; SILVA, K.C.O.; PINHO, M.A.B.; CURTI, S.P.; PAIVA, T.M. \& SANTOS, C.L.S. - Molecular characterization of influenza B virus outbreak on a cruise ship in Brazil 2012. Rev. Inst. Med. Trop. Sao Paulo, 56(3): 185-9, 2014.

However, people who have not been vaccinated during the previous season and who plan to travel during the summer should get vaccinated ${ }^{6}$. It is important to get vaccinated at least two weeks prior to the cruise, as it takes about two weeks for protective antibodies to develop ${ }^{6}$.

Two antigenically and genetically distinct lineages of influenza B viruses, represented by the reference strains B/Victoria/2/87 and B/ Yamagata/16/88, have co-circulated in humans since at least $1983^{17}$. In Brazil, surveillance of the influenza B virus over a period of 12 years demonstrated the pattern of circulation of the two influenza B/lineages. The influenza B/Victoria lineage reemerged during the 2002 influenza season and predominated during the 2003, 2004, 2007, 2010, 2011 and early 2012 influenza seasons. In contrast, the co-circulation of the two influenza B/lineages was detected during the 2002, 2005, 2006 and 2008 influenza seasons ${ }^{15}$. So far, according to $\mathrm{WHO}^{24,25}$, the 2011-12 influenza vaccines used are a good match for the strain found in the outbreak, meaning it elicits antibodies for the viruses that are actually circulating. Early data from the $\mathrm{CDC}^{5}$ suggests that this year's vaccine is about $60 \%$ effective. To our knowledge, based on the standardized written questionnaire for the systematic recording of each patient's demographic and clinical characteristics (according to the clinical form of the National Influenza Surveillance Network), the fatal case did not receive an influenza vaccination. It is important to emphasize that the following recommended groups get an influenza vaccination: all persons who (1) are aged six months through two years; (2) are aged 60 years and older; (3) have chronic pulmonary, cardiovascular, renal, hepatic, neurologic, hematologic, or metabolic disorders; (4) are immunosuppressed; (5) are or will be pregnant during the influenza season; (6) are Native American Indians; (7) are morbidly obese; (8) are health-care personnel; and (9) are exposed to a prison population ${ }^{13}$. According to the National Immunization Program, an increase in the influenza vaccine coverage has been noticed in Brazil: 84\% (2011), 86\% (2012) and 92\% (2013), surpassing the initial goal of $80 \%$ vaccine coverage ${ }^{14}$.

The vaccine strain composition for influenza $B$ was changed to the $B /$ Yamagata-like virus for use in the 2012-13 influenza season in both the northern and southern hemispheres. Influenza vaccines administered in most countries over the past five years have included only a B/Victorialike virus; as a result, a significant proportion of the world population, especially including young children, has not had the exposure to those viruses to develop natural immunity. Immunization against B virus strains of one lineage provides limited cross-protection against strains in the other lineage ${ }^{2}$. Because of this, and the difficulty of predicting which $\mathrm{B}$ virus lineage will predominate during a given season, inclusion of a second influenza B vaccine virus strain in seasonal influenza vaccines has been proposed. A recent analysis indicates that the impact of such a quadrivalent vaccine could result in a modest reduction in influenzaassociated outcomes, depending upon adequate vaccine supply, coverage, effectiveness and the incidence of influenza associated with the two B lineages ${ }^{16}$. Thus, it is crucial to have an intensive surveillance of circulating viruses worldwide. The rRT-PCR Influenza Panel served as an effective emergency tool for the rapid detection of an outbreak and pandemic of the virus in many countries, and was essential for emergency response implementation ${ }^{18}$. Laboratory disease surveillance using rapid viral diagnostic testing contributes to the control measures for influenza, a vaccine-preventable disease. In addition, molecular analysis is a very important tool to characterize the pathogen responsible for the outbreak.

\section{RESUMO}

\section{Caracterização molecular de surto de vírus influenza B em cruzeiro marítimo no Brasil 2012}

Em fevereiro de 2012, durante a temporada de verão no Brasil, um surto de doença respiratória ocorreu no navio de cruzeiro MSC Armonia. Mulher de 31 anos, membro da tripulação, foi internada com insuficiência respiratória e morreu. Com o objetivo de estudar a etiologia da doença foram investigadas necrópsia de tecido do caso fatal e secreções respiratórias de 13 passageiros e membros da tripulação com sintomas respiratórios. O teste de influenza por RT-PCR em tempo real foi realizado e o gene completo da hemaglutinina (HA) das amostras positivas foi sequenciado. $\mathrm{O}$ vírus influenza $\mathrm{B}$ foi detectado em sete indivíduos, sugerindo-o como a causa do surto de doença respiratória a bordo do navio. A análise da sequência do gene da HA indicou que os vírus estão fortemente relacionados com o vírus B/Brisbane/60/2008, linhagem Victoria, componente da vacina de influenza para 2011-2012 no hemisfério sul. Uma vez que a composição da vacina foi alterada para uso na temporada de 2012-2013, é essencial a vigilância ativa dos vírus circulantes em todo o mundo. A análise molecular é uma ferramenta importante para caracterização do patógeno responsável pelo surto. Além disso, a vigilância de doenças baseada em dados laboratoriais contribui para as medidas de controle da influenza, uma doença imunoprevinível.

\section{ACKNOWLEDGMENTS}

We would like to thank the technical assistance from Juliana Cristina Pereira and the financial support from Adolfo Lutz Institute, Ministry of Health of Brazil, Centers for Disease Control and Prevention and World Health Organization.

\section{REFERENCES}

1. Associação Brasileira de Cruzeiros Marítimos (ABREMAR). Cruzeiros marítimos: estudo de perfil e impactos econômicos no Brasil. Rio de Janeiro: ABREMAR, Fundação Getúlio Vargas; 2012. Available from: http://www.brasilcruise.com. br/_arquivos/ESTUDO\%20FGV\%20-\%20Abremar\%202011.pdf

2. Belshe RB, Coelingh K, Ambrose CS, Woo JC, Wu X. Efficacy of live attenuated influenza vaccine in children against influenza $\mathrm{B}$ viruses by lineage and antigenic similarity. Vaccine. 2010;28:2149-56.

3. Brotherton JM, Delpech VC, Gilbert GL, Hatzi S, Paraskevopoulos PD, McAnulty $\mathrm{JM}$, et al. A large outbreak of influenza A and B on a cruise ship causing widespread morbidity. Epidemiol Infect. 2003;130:263-71.

4. Centers for Disease Control and Prevention (CDC). Influenza B virus outbreak on a cruise ship - Northern Europe, 2000. MMWR. 2001;50:137-40.

5. Centers for Disease Control and Prevention (CDC). Early estimates of seasonal influenza vaccine effectiveness -United States, January 2013. MMWR. $2013 ; 62(2): 32-5$

6. Centers for Disease Control and Prevention (CDC). Traveler's Health. [Cited 2013 Aug 01]. Available from: http://wwwnc.cdc.gov/travel/page/seasonal-flu-travel.htm

7. European Centers for Disease Prevention and Control (ECDC). Influenza virus characterization. Summary Europe, April 2011. Available from: http:// www.ecdc.europa.eu/en/publications/Publications/1105_Influenza_virus_ characterisation_2011_May.pdf 


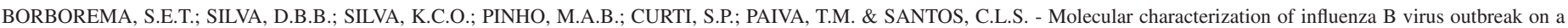
cruise ship in Brazil 2012. Rev. Inst. Med. Trop. Sao Paulo, 56(3): 185-9, 2014.

8. Hall, TA. BioEdit: a user-friendly biological sequence alignment editor and analysis program for Windows 95/98/NT. Nucleic Acids Symp Ser. 1999;41:95-8.

9. McCarter YS. Infectious disease outbreaks on cruise ships. Clin Microbiol Newsl. 2009; 31(21):161-8.

10. Miller JM, Tam TW, Maloney S, Fukuda K, Cox N, Hockin J, et al. Cruise ships: high-risk passengers and the global spread of new influenza viruses. Clin Infect Dis. $2000 ; 31: 433-8$.

11. Ministério da Saúde. Brasil. Surto de influenza B no navio de cruzeiro MSC Armonia Brasília: Ministério da Saúde; 2012. [Cited 2012 Feb 24]. Available from: http://portal. saude.gov.br/portal/aplicacoes/noticias/default.cfm?pg=dspDetalheNoticia\&id_ area $=1498 \&$ CO_NOTICIA $=13734$

12. Ministério da Saúde. Brasil. Anexo I. Recomendações frente aos casos de Influenza B no Navio de Cruzeiro MSC Armonia. Brasília: Ministério da Saúde; 2012. [Cited 2012 Feb 24]. Available from: http://portal.saude.gov.br/portal/arquivos/pdf/ recomendacoes_influenza_navio_harmoria_24022012.pdf

13. Ministério da Saúde. Brasil. Campanha Nacional de Vacinação Contra a Influenza Ano 2013. Brasília: Ministério da Saúde; 2013. [Cited 2013 Apr 01]. Available from: http://portal.saude.gov.br/portal/arquivos/pdf/informe_tecnico_campanha influenza_2013_svs_pni.pdf

14. Ministério da Saúde. Brasil. SI-PNI. Sistema de Informação do Programa Nacional de Imunizações. Campanha Nacional de Vacinação Contra Gripe. Brasília: Ministério da Saúde; 2013. [Cited 2013 Aug 01]. Available from: http://pni.datasus.gov.br/ consulta_influenza_11_selecao.asp?naofechar=N\&enviar=ok\&grupo=todos\&faixa $=$ todos $\&$ sel $=$ coberturas

15. Paiva TM, Benega MA, Silva DB, Santos KC, Cruz AS, Hortenci MF, et al. Evolutionary pattern of reemerging influenza B/Victoria lineage viruses in Sao Paulo, Brazil, 1996-2012: implications for vaccine composition strategy. J Med Virol. 2013;85:1983-9.

16. Reed C, Meltzer MI, Finelli L, Fiore A. Public health impact of including two lineages of influenza B in a quadrivalent seasonal influenza vaccine. Vaccine. 2012;30:1993-8.
17. Rota PA, Wallis TR, Harmon MW, Rota JS, Kendal AP, Nerome K. Cocirculation of two distinct evolutionary lineages of influenza type B virus since 1983. Virology. 1990;175:59-68.

18. Shu B, Wu KH, Emery S, Villanueva J, Johnson R, Guthrie E, et al. Design and performance of the CDC real-time reverse transcriptase PCR swine flu pane for detection of 2009 A (H1N1) pandemic influenza virus. J Clin Microbiol 2011;49:2614-19.

19. Tamura K, Peterson D, Peterson N, Stecher G, Nei M, Kumar S. MEGA5: molecular evolutionary genetics analysis using maximum likelihood, evolutionary distance, and maximum parsimony methods. Mol Biol Evol. 2011;28:2731-9.

20. Uyeki TM, Zane SB, Bodnar UR, Fielding KL, Buxton JA, Miller JM, et al. Large summertime influenza A outbreak among tourists in Alaska and the Yukon Territory. Clin Infect Dis. 2003;36:1095-102.

21. Ward KA, Armstrong P, McAnulty JM, Iwansenko JM, Dwyer DE. Outbreaks of pandemic (H1N1) 2009 and seasonal influenza A(H3N2) on cruise ship. Emerg Infect Dis. 2010;16:1731-7.

22. World Health Organization (WHO). Sequencing primer and protocol: 12 May 2009 Geneva: World Health Organization; 2009. Available from: http://www.who.int/csr/ resources/publications/swineflu/GenomePrimers_20090512.pdf

23. World Health Organization (WHO). CDC protocol of real-time RT-PCR for influenza H1N1. Geneva: World Health Organization; 2009. Available from: http://www.who. int/csr/resources/publications/swineflu/realtimeptpcr/en/index.html

24. World Health Organization (WHO). Recommended composition of influenza virus vaccines for use in the 2011 southern hemisphere influenza season. Geneva: World Health Organization; 2010. Available from: http://www.who.int/influenza/vaccines/ virus/recommendations/201009_Recommendation.pdf

25. World Health Organization (WHO). Recommended composition of influenza virus vaccines for use in the 2012 southern hemisphere influenza season. Geneva: World Health Organization; 2011. Available from: http://www.who.int/influenza/vaccines/ virus/recommendations/2011_09_recommendation.pdf

Received: 7 February 2013

Accepted: 8 October 2013 